Double-Faced State: Political Patronage and the Consolidation of Democracy in Turkey Author(s): Metin Heper and E. Fuat Keyman

Source: Middle Eastern Studies, Vol. 34, No. 4, Turkey before and after Atatürk: Internal and External Affairs (Oct., 1998), pp. 259-277

Published by: Taylor \& Francis, Ltd.

Stable URL: https://www.jstor.org/stable/4283977

Accessed: 30-01-2019 12:54 UTC

JSTOR is a not-for-profit service that helps scholars, researchers, and students discover, use, and build upon a wide range of content in a trusted digital archive. We use information technology and tools to increase productivity and facilitate new forms of scholarship. For more information about JSTOR, please contact support@jstor.org.

Your use of the JSTOR archive indicates your acceptance of the Terms \& Conditions of Use, available at https://about.jstor.org/terms

Taylor \& Francis, Ltd. is collaborating with JSTOR to digitize, preserve and extend access to Middle Eastern Studies 


\title{
Double-Faced State: Political Patronage and the Consolidation of Democracy in Turkey
}

\author{
METIN HEPER and E. FUAT KEYMAN
}

Turkey has had a strong state tradition in the sense that, from the time of the Ottoman Empire to the present, there has always been a particular category of elite, who acted in the name of the state by assuming virtually complete autonomy from other groups in the polity, including the political elite. In the Ottoman Empire, the state elite was particularly preoccupied with the problem of reforming the Ottoman military and government along Western lines. ${ }^{1}$ In the Republican period (from 1923 to the present), the state elite, including 'the intellectual-bureaucratic elite' and military, has been instrumental in introducing Westernizing reforms in government and society. The state elite has always acted primarily as the defender of the reforms, in particular secularism. ${ }^{2}$ It also played a dominant role in socioeconomic life.

However, since the transition to a multi-party democracy in 1945, Turkish modernization also involved the pursuit of the strategy of political patronage, with respect to the way in which the political elite approached socio-economic problems. ${ }^{3}$ With the exception of the 1961-65 and 1983-87 periods, almost no effort has been made to develop coherent socioeconomic policies; instead, the political elite tended to be overly responsive to the demands of particularistic socio-economic issues. What passed as 'policies' on such matters were, on the whole, no more than slipshod decisions essentially motivated by a desire to garner votes.

Thus, politics has not revolved essentially around the pros and cons of socio-economic policies; political patronage became the basic strategy of obtaining votes, in which religion was frequently used for political purposes. This led to a confrontation between the state elite and the political elite. When the state elite perceived a serious threat to such republican values as secularism, democracy was discontinued, for a limited period, because of the state elite's commitment to Westernization and, therefore, to democracy.

This essay elaborates on this double-faced quality of the state in Turkey - strong and weak - and on the adverse effects of the weak state and the 
strategy of political patronage for democracy. It also addresses the question of whether, in the near future, Turkey can attain a healthy combination of a strong state (prudence) and a weak state (responsiveness), which, of course, is a prerequisite for a viable democracy.

As noted, in the pre- 1950 period, Turkey was ruled under a single-party regime. During this era, the founders of the Republic, Atatürk and İnönü, emerged as the defenders of the long-term interests of the community and, thus, as the proponents of a strong state. Consequently, the socio-economic policies they pursued were strongly coloured by their 'high politics.' For instance, İnönü governments insisted on balanced budgets in order not to be dependent on foreign aid. These governments were engaged in a major railroad construction project so that, in time of war, personnel and equipment could be transferred quickly from one part of the country to another. The government started extensive educational programmes in order to educate new generations of Turks to believe in the virtues of the new Republican regime. ${ }^{4}$ Along the same lines, the socio-economic dimension of populism, as it emerged during the War of Independence, emphasized the necessity of improving the living standards of the people by the application of modern science and technology to the achievement of national progress. ${ }^{5}$ Also, İnönü always stood firm against those who tried to use political office for economic gain; he always started legal proceedings against officials and politicians suspected of having been engaged in corruption. ${ }^{6}$

Consequently, relatively coherent socio-economic policies could be devised during this era. In the 1920s a liberal economic policy was adopted. Soon, this approach to the economy proved to be less than satisfactory, because there was a lack of private capital and vigorous and experienced private entrepreneurs. Also, the economy did not have the basic infrastructure. Moreover, at the end of the decade, the 1929 Great Depression hit the world economy. Thus, there was a shift to pragmatic etatism. The state took upon itself an active entrepreneurial role out of necessity rather than for ideological reasons. ${ }^{7}$ The state actively became involved in a number of economic activities, including the establishment of exchange controls, major public investments in manufacturing, the nationalization of foreign and local companies delivering public services, and the imposition of import duties and quotas to protect industry. Private manufacturing started to develop under the tutelage of the state. ${ }^{8}$ Capital began to be accumulated through contracts with the state. ${ }^{9}$ In the singleparty period in question, the groundwork was successfully completed for Turkey's later rapid industrialization.

The process of capital accumulation through contracts with the state was 
the beginning of the formation of vertical links between the state and society at the expense of effective horizontal links among members of the same social classes. Individual entrepreneurs became successful due to special protections granted to them by the state. During the single-party decades, the state tended to extend the scope of such special protections in order to create the necessary requirements of economic modernization. The state elite did not consider such protections as a means of political patronage to obtain political support. It was rather an integral part of their commitment to Westernization.

The exercise of political patronage in return for votes became paramount only with the coming to power of the centre-right Democrat Party (DP) in 1950 and the successor centre-right political parties to the DP - the Justice Party (AP) and the True Path Party (DYP). Later other political parties, including those on the left, also followed suit. During the DP government, the earlier state-centred polity began to move in the direction of a political party-centred polity; the political elite began to replace the state elite as the major public policy-makers. The state elite, themselves, maintained veto powers, as it became apparent with the three military interventions and with the fall of the Erbakan-Çiller government in 1997. For their part, the political elite remained as unresponsive to civil society as the state elite concerning the general 'policies' they pursued. ${ }^{10}$ Instead, in order to garner votes they formed links with leading economic interest group associations and some key persons such as local notables and others who could mobilize votes for them.

In the multi-party democracy of post-1950 Turkey, several factors contributed to the flourishing of patronage politics. For one thing, the traditionally strong state quickly found its adversaries among the new political elite. The latter presented themselves as the proponents of the 'national will' against the 'state's will', and as the protectors of the masses against the state elite. This was an instinctive reaction on the part of the new political elite against the state elite who for long dominated the polity and society as well as towards those bureaucrats, whose self-designated mission of safeguarding the Republican norms was far more important than administrative merit - efficient and effective implementation of policies adopted by the new political elite. " The new political elite also tried 'to protect the people against the corrupt and tyrannical government officials'. ${ }^{12}$ Many did need such a protection because, as a consequence of the rapid socio-economic change from 1950 onward, the traditional webs of protection had begun to crumble, ${ }^{13}$ while the ethics of belonging, solidarity and intimate relations, as opposed to individualism, continued to be salient. ${ }^{14}$ Consequently, elected representatives needed to be direct personal representatives of the people. ${ }^{15}$ In the process, the party system became 
extremely responsive to the localized and particularistic demands of its constituencies..$^{16}$ Also, a highly unequal distribution of income placed many in need of special favours; ${ }^{17}$ the multi-party system created incentives to use the resources of the state to win political competition; ${ }^{18}$ and the increased scope of the public sector facilitated to meet the localized and particular demands of the constituencies through political patronage. ${ }^{19}$

On the other hand, in the making of policies, political responsiveness to, let alone regular consultations with, organized interests have remained alien to the Turkish scene. ${ }^{20}$ In formulating policies, the political elite, not unlike the state elite, perceived nothing wrong in depriving themselves of the benefits of close consultation and cooperation with the business groups. ${ }^{21}$ Therefore, there has emerged in Turkey neither an effectively functioning Social and Economic Council, within the framework of which representatives of the government, private sector and labour could confer and determine certain targets, nor interest group associations that could efficaciously impinge on governments. ${ }^{22}$

From 1950 onward, the political parties in Turkey increasingly resembled ventures established to promote solely their members' economic interests. ${ }^{23}$ As noted, the origins of such party structures in Turkey harked back to the DP of the 1950s, which emerged as a political machine - an organization interested less in political ideals and more in securing and holding office for its leaders and distributing income to those who ran it and worked for it through patron-client networks and to those who voted for the party through pork-barrel grants such as roads, schools, electricity, mosques, and the like. ${ }^{24}$ Based essentially on a myriad of patron-client relations, the DP was bound to lack elements of political institutionalization, including autonomy and coherence. ${ }^{25}$ Without the latter characteristics - the DP and its successor parties, as well as other political parties, could hardly develop rationally formulated public policies. In any case, political parties have remained indifferent to rational policy-making. They did not have research bureaux let alone think-tanks for this purpose. ${ }^{26}$ Also, they hardly paid attention to carefully prepared and debated policy proposals by independent research foundations and think-tanks. ${ }^{27}$ As a result, politicians made promises which were not based on a careful analysis of the situation; in fact, they often made decisions on the spot. ${ }^{28}$ It was not, therefore, surprising that, for instance, the decade of the 1950s was characterized by 'careless and uncontrolled high growth rates'. ${ }^{29}$

As a result of this state of affairs, the party programmes in Turkey turned out to be nothing more than window dressing. They, in fact, very much resembled each other, consisting of long lists of promises with no mention of how those promises were going to be fulfilled ${ }^{30}$ A recent study has found that in the formation of coalition governments, in twenty countries with 
well-established democracies, if the political regime was threatened, all system parties tended to pool their resources together and tried to deal with that problem. If the political milieu had a left-right divide the political parties on either side of that divide attempted to form governments within their own camp. If neither of these two situations obtained, the political parties were often attracted to those parties with similar policy lines. ${ }^{31}$ In Turkey, none of the above conditions played a significant role in the formation of coalition governments. Instead, agreements among the political parties in Turkey were almost always based on short-term and tactical matters; the parties were preoccupied with trying to prevent other political parties from making electoral gains through exercising patronage powers and not with attempting to convince the electorate about the merits of their policies and programmes. ${ }^{32}$

This was because, as noted, politics in Turkey has not revolved around the pros and cons of political parties' policies and programmes. Parliamentary activities in Turkey have tended to be based on grand spoils operations; there was little concern with other functions. Individual parliamentarians felt under constant pressure to repay their 'debt' to their narrowly defined constituencies; they were not interested in debate, deliberation and policy-making. In any case, they were not expected to make such contributions. ${ }^{33}$ Those parliamentarians, who were skilled in developing benefit networks, came to have an advantage over those who had a strong background in policy-making. ${ }^{34}$ Skill in personal relations was more valued than expertise. ${ }^{35}$ Wealth was also important; those party members who could finance party activities at the local level thought they deserved to be, first, the chairpersons of local party organizations and, then, parliamentarians. ${ }^{36}$ One study has listed the typical characteristics of a parliamentarian in Turkey as follows: being wealthy, having a large network of acquaintances, the ability to make promises in a persuasive tone even if the parliamentarian has no intention of delivering what is promised, skill in bargaining, maximizing one's own interests rather than those of the people, and the like. ${ }^{37}$

In turn, party leaders were not in need of new ideas and programmes to keep their places. ${ }^{38}$ In ministers, on the whole, loyalty rather than merit was sought. They were not expected to have independent opinions of their own, for the Councils of Ministers was dominated by the Prime Minister. ${ }^{39}$ Since 1950 the bureaucracy therefore has been increasingly politicized. ${ }^{40}$ Political parties were not interested in positive contributions the bureaucracy could make to the formulation of policies. Rather, they tried to curb the power of the bureaucracy for their own purposes - being able to pursue their particular aims without any interference from the bureaucracy. ${ }^{41}$

During the $1950 \mathrm{~s}$, however, the state elite was very critical of some of 
the economic measures of the DP governments. They opposed granting foreign companies the right to search for oil and providing incentives to foreign investors. They also opposed the 'anti-secularist' policies of the DP governments. The state elite also emphasized the need for (indicative) planning in order to render economic decision-making more rational. ${ }^{42}$ Moreover, when DP governments began to run out of resources to distribute to their supporters and they began to use religion to garner votes, the clash between political and state elites occurred. Consequently, the DP governments resorted to authoritarianism and this move triggered the 1960 military intervention.

The 1961 Constitution was an effort to re-institutionalize the State in Turkish politics with (1) the National Security Council, comprised of some ministers and the members of the High Command, (2) the Constitutional Court, (3) the State Planning Organization, (4) the autonomous State Radio and Television Agency and universities, and (5) the Council of State (the Turkish version of France's Conseil d'Etat), with additional powers. The 1961 Constitution was also a 'programmatic' constitution; it spelled out government's economic goals to be achieved through planning.

The first group of planners in the early 1960s insisted that the political elite should not interfere with socio-economic planning. Within the coalition governments, formed during the 1961-65 period between the prostate Republican People's Party (CHP) on the one hand and such anti-state parties as the AP and the New Turkey Party on the other, politicians from both camps became engaged in intense conflict on the issue of planned versus unplanned economy. Still, during this period there was a relative lull in patronage politics. Planning instead of patronage, industrial growth instead of populism, and an urban, polished universalism instead of rural parochialism were emphasized. ${ }^{43}$

With the coming to power of Süleyman Demirel's AP - the successor party to the DP - clientelism returned to Turkish politics. In addition to the DP tradition that the AP inherited, Demirel's personality characteristics and his political philosophy were also conducive to the re-emergence of patronage politics in Turkey. Demirel came from a small village in western Turkey. For many, he was the image of the people's man; Demirel himself enjoyed having that image. He was in favour of the exercise of 'the national will' unhindered by the state elite. This led him to embrace a populist and majoritarian conception of democracy, with non-mediated mass political participation. Demirel, thus, had a strong commitment to improve the lot of the masses; in the absence of a political tradition of competing to come up with better policies this led him to adopt distributive policies. ${ }^{44}$

Consequently, in the post-1965 period, patronage politics resurfaced in earnest. ${ }^{45}$ It is true that economically the AP was more liberal than the DP, 
yet, just as in the DP period, ${ }^{46}$ the state economic enterprises - a major means of political patronage - continued to flourish. Demirel tried to please everybody, including business and labour at the same time. ${ }^{47}$ This was a difficult task to fulfil particularly in the post-1965 period. The 1961 Constitution had not only re-institutionalized the state but it had also expanded the scope of basic rights and liberties. The primary motive behind the expansion of basic rights and liberties was that of protecting the state elite against the 'tyranny of the majority'. However, the new Constitution also made possible the development of ideologies on the Left and the Right and, thus, the gradual crystallization of a class conflict. The economic independence of the peasants was also increased, while their dependence on the meager resources of the merchants decreased; as a result, the bargaining power of the voter vis-à-vis the government grew. ${ }^{48}$

These developments took place at a time when Turkey faced a structural trade deficit, which steadily deteriorated over time due to the stagnation of exports and the expansion of necessary imports ${ }^{49}$ and when the 1974 and 1979 world-wide oil crisis occurred. What needed to be done was to persuade labour to accept income policy the corporate capital to seek accommodation with labour. However, the government, controlled by the political elite, was not coherent enough to force a new consensus that required such mutual concessions..$^{50}$ Steeped in patronage politics and, thus, having had vertical relations with individual members of the nascent social classes and having a condescending and dominant attitude toward civil societal groups, the political elite could not exercise social control, that is 'the successful subordination of people's own inclinations of social behaviour or behaviour sought by other social organizations in favour of the behaviour prescribed by state rules', ${ }^{51}$ to bring about the consensus in question.

The result was the escalation of the clash between the armed Left-Right groups and also, at times, sectarian confrontations. The crises both in 1971 and 1980 were defused by the military that either temporarily became the real power behind an 'above party' government formed at its behest, as in the 1971-73 'coup by communiqué', or took power directly into its hands, as in the 1980-83 intervention. Throughout the 1960s and 1970s the military remained the most coherent and professional institution. After purging the radicals amongst its ranks, the military, acting as the state elite, could live with patronage-oriented governments but not with the extreme polarization in the polity and society that, in their view, threatened Westernizing reforms - in particular secularism - and the national unity and the territorial integrity of the country.

In 1983 the three-year interregnum after the 1980-military intervention ended and the Motherland Party (ANAP), under Turgut Özal, became the 
governing party which ruled the country until 1991. From 1980 onward, Özal played a key role in the liberalization of the economy and in the shift from import substitution to export orientation in Turkey. It is true that these shifts in the economic policy were the products of a 'forced decision', following the acute economic crisis of the late 1970s. ${ }^{52}$ However, the fact that these and related decisions could be taken at all was significant in itself, for they were important steps toward a strong state, vis-à-vis the economy.

Özal emerged as a leader with a vision. He placed emphasis on economic rationality. Thus, in the early Özal period, economic decisions tended to be responsive to market signals, ${ }^{53}$ they were not dictated by clientelist demands, and, relatively speaking, they were not the products of slipshod political or bureaucratic decisions. Entrepreneurial activity began to be appreciated and market values such as efficiency gained much salience. The boundaries of what business could expect from the government were quite clearly set: progressively, the government was to have less control over private sector, to reduce protection from imports and enhance export orientation, thereby opening Turkish economy to world market. ${ }^{54}$

This reorientation in economic policy had some positive results. The exports/GDP ratio grew from 4.9 per cent in 1979 to 20.9 per cent in 1985, while the annual economic growth rate averaged 5.3 per cent between 1981 and $1986 .{ }^{55}$ Inflation, which was 108 per cent in 1980, dropped to 29.6 per cent in 1986. Similarly, while in 1980 the growth rate of GNP was -1.1, in 1986 it rose to $8.1 .{ }^{56}$ Between 1980 and 1990 the value of exports increased from US $\$ 2.9$ billion to US $\$ 13.0$ billion and, in the same period, the share of manufactured goods in total exports increased from 29 to 79 per cent. ${ }^{57}$

It is true that the economic success story of the early part of the $1980 \mathrm{~s}$ in Turkey was given a boost by the fact that between 1980 and 1983, the military brought major restrictions to trade union rights and labour's bargaining power. However, even after the transition to multiparty politics in November 1983, considerable restrictions over labour's bargaining power continued to be a major feature of the system. ${ }^{58}$ One reason why the ANAP governments could keep the lid on demand was the fact that until 1987 the political patronage-oriented political cadres of the pre-1980 period were barred from participating in active politics. In addition, Özal focused his attention on the economy; since successful economic performance was dependent on political stability, Özal pursued a policy of reconciliation and harmony in areas other than the economy. Among other things, he refrained from engaging in debate on critical issues and tried to improve Turkey's relations even with such neighbouring countries as Iran and Syria with whom, for a long time, Turkey had not had friendly relations. Also critical here were Özal's related efforts to de-emphasize ideology in Turkish politics. Özal explained the raison d'être behind his founding the ANAP as 
that of bringing under one roof the four political tendencies represented in the pre-1980 period by the (centre-right) AP, the (centre-left) CHP, the (religiously oriented) National Salvation Party and the (ultra-right) Nationalist Action Party. He thought of the ANAP as a catch-all party. ${ }^{59}$

The ANAP was going to 'catch all' not through patronage politics but through well-formulated and clearly explained policies. ANAP had weak links to the localities ${ }^{60}$ probably on purpose. Özal chose to reach the voters directly, through regular appearances on television, and explain in simple language the dynamics of the economy, the constraints his governments faced, and the measures they were going to take. He proved to be quite persuasive. ${ }^{61}$

Despite the fact that the ANAP under Özal had adopted a novel approach to the economy, the style of rule during this period also evinced some continuities with the previous decades and this state of affairs facilitated the return to patronage politics from the second part of the 1980s onward. It is true that, as compared to such previous leaders as Menderes and Demirel, Özal seems to have consulted others more frequently before making decisions. ${ }^{62}$ This was only to be expected, because Özal had a grand project the achievement of which dictated that he act according to a set of market rules. However, Özal used others basically as suppliers of data; otherwise, he made all the critical decisions himself. ${ }^{63}$ Such extreme centralization of policy-making did not help to develop the institutionalization of collaboration between the state and business. Consequently, it proved difficult to obtain concessions from business where it was necessary. Some powerful and well-organized groups in the economy continued to show effective resistance to extensive tax reform or, at least at the time, to a widespread privatization programme. Also, during this period, there was a reluctance to delegate authority to the managers of state economic enterprises, while the overall weight of the public sector in the economy continued and even increased. ${ }^{64}$ In 1979 the share of the public sector in total fixed investment was 50 per cent and its total fixed capital investment represented 22 per cent of GNP; in 1987, those figures were 54 and 24 per cent, respectively. ${ }^{65}$ The annual inflation rate, which averaged 33 per cent in the early $1980 \mathrm{~s}$, reached 75 per cent in $1988 .{ }^{66}$

Furthermore, as noted, in the bureaucracy there were only 'pockets of efficiency'; otherwise, the Özal government had been unable to 'outgrow the narrow and weakly-rooted universalism of the bureaucracy and to transform it into a socially-grounded industrial (bourgeois) universalism' ${ }^{67}$ For instance, in 1987, when the ANAP government was criticized in Parliament for having signed the Council of Europe's Convention against Torture rather late, the then Foreign Minister Mesut Yilmaz heaped the blame primarily on the inefficiency of the bureaucracy. ${ }^{68}$ 
Following the 1984 local elections in which, as compared to the 1983 general elections, the ANAP's votes decreased, particularly with the return of the previous political leaders to active politics and the relaxation of constraints in trade union activity in 1987, virtually full-scale patronage politics returned ${ }^{69}$ As ANAP could not survive in this new (old) game of politics by pursuing its previous policies, it, too, drifted to patronage politics. $^{70}$ While the percentage increase in staff positions in the Civil Service was 2.4 in 1985 and 3.0 in 1986, it jumped to 10.0 in $1987 .{ }^{71}$ More generally, after a downward trend observed from 1982 to 1988, current public expenditure increased from 34.5 per cent in 1988 to almost 50.0 per cent in 1990. This was basically due to wages and salary increases granted to public employees in 1989. ${ }^{72}$ While in 1983 and 1984, the resources devoted to agricultural producers hovered little over ten per cent of the round value of their crops, in 1987 it rose to 30 per cent and in 1991 to 40 per cent. ${ }^{73}$

Patronage politics further increased in the post-1991 period ${ }^{74}$ and reached its peak in 1996-97. The rise in political patronage in the 1991-95 period was due to the return of Demirel and his cadres to government and to the fact that Demirel's new party DYP basically represented the 'losers' in the 1983-87 structural adjustment programme of ANAP. These included large industrial groups with a predominantly internal market orientation, agricultural interests, and a large component of wage- and salary-earners. ${ }^{75}$

Demirel spent the first three months of his stay in power by 'receiving delegates from his party's local branches, giving speeches, listening to their demands, and making promises' ${ }^{76}$ His favourite line was, 'My workers, my villagers, my civil servants'. He was everybody's 'father'. Meanwhile Tansu Çiller, the minister responsible for economic affairs in the DYPSocial Democratic People's Party (SHP) coalition government led by Demirel, came up with her 'National Dynamic Equilibrium Model' that aimed at lowering interest rates and inflation, boosting the stock exchange, and starting a major reform of state economic enterprises. This was a pet project of Ciller herself; in preparing it she had not consulted the Undersecretariat of Treasury and Foreign Trade, the Central Bank, and/or the State Planning Organization. ${ }^{77}$

During the early years of the DYP-SHP coalition, Çiller presented herself as a proponent of discipline in the economy. For instance, she protested against 'the appointment of 100 persons to state economic enterprises every day'. ${ }^{78}$ Demirel, however, gave assurances that the government was going to provide 'work for everybody'. ${ }^{79}$ On another occasion Demirel said, 'The rights that had been usurped [by the past governments] will be returned to their true owners. ${ }^{180}$ In an economic reform programme, enunciated in January 1992, the government aimed at 
ambitious goals: lowering inflation and keeping it at low levels, bringing increases in production, improving the distribution of income, seeing to it that the market functioned in a healthy manner, achieving an integration of the Turkish economy with the world economy, expanding ownership in Turkey, and, more generally, raising people's welfare.$^{81}$ Leaving aside the fact that it is always very difficult, if not impossible, to realize all of these goals at the same time, the policies pursued aimed only at pleasing all major social groups: industry was supported by a low tax burden, as well as low input costs to compensate for rising wages; labour was compensated by high wage increases; and farmers were given high prices for their agricultural products. In 1993 almost the whole of the government's budgetary funds were allocated to current expenditures (mainly wage and salary payments 34.9 per cent), interest payments on domestic and external debt, and the transfer payments, leaving very little for public investment - only 11.0 per cent. $^{82}$

Demirel's weak state caused Turkey to drift towards the economic crisis of April 1994. There had been a rapid increase in expenditures without a parallel increase in tax revenues. A growing current account deficit could only be covered by inflows of primarily short-term capital. The large current account deficit, in turn, was the outcome of a real appreciation of the exchange rate that undermined the growth of the export sector while, at the same time, encouraging a rapid increase in imports. To make things worse, in response to the growing disequilibrium in the economy the two major international credit rating institutions reduced the country's credit rating, which led to a crisis of confidence on the part of the investors and resulted in a significant outflow of short-term capital. ${ }^{83}$ The newspapers began reporting astonished people mumbling, as early as summer 1992, 'Father, what have you done to us?' ${ }^{84}$ Despite the growing cries of protest from 'Demirel's workers', 'Demirel's villagers' and 'Demirel's civil servants', those representing the strong state - the military - did not lift a finger because the economic crisis in question only indirectly threatened the vital interests of Turkey.

In 1993 Demirel became president. With his withdrawal from the day-today running of the government, Turkey lost its last political leader with vision. It is true that Demirel was quite responsive to particular demands but, at the same time he had great ideals for Turkey. In post-Demirel Turkey, prime ministers had either narrow visions (as was the case until recently Mesut Yllmaz, leader of the ANAP, twice prime minister for brief periods before July 1997), or they had few ideals (e.g. Tansu Çiller, of the DYP, Prime Minister in 1993-95 and Deputy Prime Minister in 1996-97), or or again they were utopian (Necmettin Erbakan, then leader of the now defunct religiouslyoriented Refah Party (RP), Prime Minister in 1996-97). It has been claimed 
that in recent years politics in Turkey has been conducted almost completely with a view not only to narrow party interests but also to sheer material interests ${ }^{85}$ and that the resources at the disposal of governments have been seen by both politicians and bureaucrats as nothing more than booty to be distributed among themselves. ${ }^{86}$

There may be exaggerations in these claims; at least, they are too sweeping. On the other hand, they seem to be not too wide off the mark. The 1996-97 coalition government between Erbakan's RP and Çiller's DYP was based on entirely instrumental motives: Erbakan wished to join the government in order to further legitimize his religiously oriented RP in the eyes of the state elite, and Çiller wanted to avoid legal proceedings because of the allegations of wrongdoing and corruption on her part while Prime Minister. ${ }^{87}$

In the Erbakan-Çiller coalition, although Çiller's DYP controlled most of the economic ministries, she could not prevent the RP from having a considerable role in the conduct of the economy. Erbakan's economic policy based on the notion of a Just Order was utopian; the party did not even pretend to implement it. ${ }^{88}$ Nevertheless, the RP came up with several economic packages, each of which contained exaggerated promises to different social groups, although the government had hardly any funds for this purpose. ${ }^{89}$ Consequently, Erbakan's statements on the economy began to be reported in the media as 'fairy tales for adults' ${ }^{90}$ The managers of the leading holding companies such as Koç and Sabanc1, ${ }^{91}$ as well as interest group associations representing business and labour, ${ }^{92}$ directed pointed criticisms at the government and wanted discipline in the economy. Çiller could not do anything about these developments because of her personal liability. ${ }^{93}$

Faced with the prospect of not delivering on the economic front, Erbakan increasingly tolerated the rising voices of militant Islam in his party. What made things even worse was Erbakan's visits to such militant Islamic states as Libya and Iran. Erbakan's RP, which at least to some people in the past, had given the impression of being a party that aimed at making Turkish society more Muslim rather than rendering the Turkish state an Islamic one ${ }^{94}$ now seemed to many, most critically to the military, as a party longing for an Islamic state. This time, however, the military chose not to make an overt intervention. ${ }^{95}$ At the 28 February 1997 meeting of the National Security Council, at the behest of its military members, the Council recommended to the government that it should take stern measures against further Islamization of the state and society. ${ }^{96}$ One of those measures included scrapping the middle school section of the Prayer Leader and Preacher Schools, thus, in effect, making an eight-year secular education compulsory for every pupil. When the DYP-RP government did not act on 
these recommendations in any great hurry, they were repeated at subsequent meetings of the Council, and the General Staff held a series of 'briefings' with members of the media, selected higher civil servants, and university administrators 'about the security threat some Islamic activities posed for the state'. These pressures on the government by the military were coupled with protests 'by the secularists' in the country ${ }^{97}$ - every night for ten minutes they turned off the lights in their premises - and the influential secularly oriented media and interest group associations representing big business, small producers and both the moderate and militant wings of labor directed sharp criticisms at the government.

For a while, the government seemed to give no heed to the increasing pressure. However, it seems that when talk began to circulate that a military intervention was imminent Ciller persuaded Erbakan that she 'the secularist' should be the Prime Minister, in order to avert a possible military take-over. Erbakan resigned in favour of his coalition partner. ${ }^{98}$ However, President Demirel did not appoint Çiller but designated Mesut Yılmaz, the leader of ANAP, as Prime Minister, despite the fact that, at the time, Erbakan and Çiller together commanded a majority in Parliament. Demirel explained that his appointment of Yllmaz was a political (read, 'prudent') rather than a 'democratic [read 'numerical'] choice'. It soon proved to be a numerical choice, too, because, in the event, the Yilmaz government obtained a vote of confidence, thanks to resignations from both Erbakan's RP and particularly Çiller's DYP. This confidence was due to the fact that many groups in the polity and society, including parliamentarians, were convinced that the state's weakness on issues not concerning the secular and democratic regime had the potential to pose a critical threat for the country.

Will Turkey be able to break the vicious circle of a weak state (in the economic sphere) giving rise to developments that invite the strong state (vis-à-vis the political regime) to take over completely or at least intervene indirectly in politics and, when things are normalized, will the weak state return to the scene and try to make up for the losses some groups experienced during the strong state period and, therefore, re-start the whole circle again? The fact that Turkey could not break this vicious circle since the transition to multi-party politics more than 50 years ago, during which time many hard core authoritarian regimes elsewhere have made significant progress toward consolidating their democracies, may make one pessimistic about the future of democracy in Turkey.

On the other hand, there are also grounds for being optimistic. In the course of the last ten years, patronage politics reached new highs and, at least on the surface, there was a concomitant rise of political Islam - they 
were both related and autonomous from each other - yet the military did not take power directly into its hands. The military acted as only one of the several pressure groups, though without doubt, the most critical one since in the last analysis only it could apply immediate and effective sanctions if the Erbakan-Çiller team insisted on staying in power. The military's not taking power into its hands was extremely useful, in that it gave a chance to the political elite to figure out where they went wrong and what to do to deal effectively with the difficult problems, confronting Turkish political, economic and social life.

It was also significant that in the months leading to the fall of the Erbakan-Çiller coalition, the military made several pleas to the political elite that, this time around, the government, and not the military, should cope with the "threat the rising political Islam posed for the secular and democratic regime in Turkey'. Consequently, many 'secularists', including some leftists who in the past had bitterly opposed the military, had praise for the military for its patience, and urged the political elite to put their house in order. This, too, may oblige the political elite to think carefully over how democracy in Turkey can be improved.

In all probability, whether the political elite strives to make that improvement will continue to be monitored not only by the media but also by other elements of civil society. For the first time in Turkish politics, civil societal groups actively joined forces with the state elite to deal with the problem of the weak state in Turkey. Thus, there is reason to think that in the near future there will be in Turkey, a judicious combination of a weak state and a strong state, or political responsiveness and political prudence. These norms, which are, in combination, the indispensable dimensions of a consolidated democracy, may be internalized by the political elite so that in the future there may not be a need for the military to act even as a critical pressure group. Such a development would also have important implications for the healthy functioning of the executive branch, Parliament, and the bureaucracy, over and above its favourable impact upon the consolidation of democracy in Turkey.

Joel S. Migdal has seen a close link between the degree of social control a state exercises and the strength of that state. He has suggested that extensive societal dislocations and/or social disturbances resulting from war and/or revolution and massive migration weaken the state's social control and transform a strong state into a weak state. ${ }^{99}$ In Turkey the state became weaker not because of extensive societal dislocations and/or social disturbances but because the political elite, largely as a reaction to the dominance of the state elite, began to pursue non-prudent and incoherent economic policies. Only at times of complete or partial depolitization of the political milieu (1923-45, 1961-65 and 1983-87 periods), selected political 
leaders (İsmet İnönü and Turgut Özal) pursued more prudent and coherent economic policies. Because of their basic commitment to democracy, the state elite did not act even when they thought that the economic policies were incoherent and irresponsible. They moved only when in their perception the Republican regime had come under a serious threat, as a consequence of other political developments, such as the armed Left-Right confrontation or the rise of political Islam. Concerning the Republican regime the state in Turkey remained strong; vis-à-vis the socio-economic sphere the state in Turkey more often than not evinced characteristics of a weak state. Because of the overall (and increasing) commitment of the state elite to democracy, although from time to time the phenomenon of the weak state led to political crises (such as short-term military interventions), it did not lead to regime crises (such as the establishment of a long-term authoritarian regime).

\section{NOTES}

This is a revised version of a paper presented at the Seventeenth World Congress of the International Political Science Association, Seoul, South Korea, August 1997. We are grateful to İzak Atiyas of the World Bank and Sabancı University, Ankara and Selçuk Sancar of the State Planning Organization of Turkey who made invaluable comments on the earlier version; we, of course, absolve them of any responsibility for the final product.

1. See Metin Heper, The State Tradition in Turkey (Walkington: The Eothen Press, 1985), Chapter Two. On military schools, see Bernard Lewis, The Emergence of Modern Turkey (London: Oxford University Press, 1961), p.181.

2. Heper, The State Tradition in Turkey, Chapters Three and Four.

3. İlkay Sunar, 'Populism and Patronage: The Demokrat Party and Its Legacy in Turkey', Il Politico, Vol.60 (1990), pp.745-57.

4. Metin Heper, Ismet Inönü: The Making of a Turkish Statesman (Leiden: E. J. Brill, 1998), Chapter Six. With the exceptions of 1939 and 1949, surpluses were recorded in the budget in the 1933-1949 period, which made possible the importation of intermediate goods. Therefore, there was an impressive average growth rate of 3.6 per cent during this period, which included the World War II years. See Devlet Planlama Teşkilat,, Ekonomik ve Sosyal Göstergeler (Ankara: Devlet Planlama Teşkilatı, 1977), p.20.

5. Kemal H. Karpat, 'The Republican People's Party, 1923-1945', in Metin Heper and Jacob Landau (eds.), Political Parties and Democracy in Turkey (London: I. B. Tauris, 1991), p.54.

6. Heper, Ísmet Inönü: The Making of a Turkish Statesman, p.175.

7. Ziya Öniş, 'The State and Economic Development in Contemporary Turkey: Etatism to Neoliberalism and Beyond', in Vojtech Mastny and R. Craig Nation (eds.), Turkey Between East and West: New Challenges for a Rising Regional Power (Boulder, Colorado: Westview Press, 1996), pp.157, 158.

8. İzak Atiyas, 'Uneven Governance and Fiscal Failure: The Adjustment Experience in Turkey', in Leila Frischtak and İzak Atiyas (eds.), Governance, Leadership, and Communication: Building Constituencies for Economic Reform (Washington, D C: The World Bank, 1996), p. 287.

9. Öniş, 'The State and Economic Development in Contemporary Turkey', p.157.

10. Metin Heper, 'The State, Political Party and Society in Turkey', Government and Opposition, Vol.25 (Summer 1990), pp.321-33. 
11. Leslie L. Roos and Noralou P. Roos, Managers of Modernization: Organizations and Elites in Turkey (Cambridge, Mass.: Harvard University Press, 1971), pp.168ff.

12. Sabri Sayarı, 'Political Patronage in Turkey', in Ernest Gellner and John Waterbury (eds.), Patrons and Clients in Mediterranean Societies (London: Duckworth, 1977), p.106.

13. Ergun Özbudun, 'Turkey: The Politics of Political Clientelism', in S. N. Eisenstadt and René Lemarchand (eds.), Political Clientelism, Patronage and Development (Beverly Hills and London: Sage, 1981), p.252.

14. Ayşe Güneş-Ayata, 'Roots and Trends of Clientelism in Turkey', in Luis Roniger and Ayşe Güneş-Ayata (eds.), Democracy, Clientelism and Civil Society (Boulder, Colorado and London: Lynne Rienner, Publishers, 1994), p.61.

15. Ibid., p.53.

16. Atiyas, 'Uneven Governance and Fiscal Failure: The Adjustment Experience in Turkey', p. 284 .

17. Öniş, 'The State and Economic Development in Contemporary Turkey', p.169.

18. Atiyas, 'Uneven Governance and Fiscal Failure: The Adjustment Experience in Turkey', p.287.

19. Özbudun, 'Turkey: The Politics of Political Clientelism', p.253.

20. Ayșe Buğra, State and Business in Modern Turkey: A Comparative Study (Albany: State University of New York Press, 1994).

21. İlkay Sunar, 'The Politics of State Interventionism in "Populist" Egypt and Turkey', in Ayşe Öncü, Çağlar Keyder and Saad Eddin Ibrahim (eds.), Developmentalism and Beyond: Society and Politics in Egypt and Turkey (Cairo: The American University in Cairo Press, 1994), p.98.

22. İzak Atiyas and Şerif Sayın, Siyasi Sorumluluk, Yönetsel Sorumluluk ve Bütçe Sistemi: Bir Yeniden Yapılanma Önerisine Doğru (Istanbul: Türkiye Ekonomik ve Sosyal Etüdler Vakfi, 1996), p.27 and Metin Heper, 'Interest-Group Politics in Post-1980 Turkey: Lingering Monism', in Metin Heper (ed.), Strong State and Economic Interest Groups: The Post-1980 Turkish Experience (Berlin and New York: Walter de Gruyter, 1991), pp.163-76. In Turkey, there is an Economic and Social Council, but it is no more than an advisory body and not much attention is paid to its advice.

23. Kamran İnan, Siyasetin İçinden (Istanbul: Milliyet Yayınlanı, 1995), p.35.

24. Sayarı, 'Political Patronage in Turkey', p.260; Ayșe Güneş-Ayata, 'Roots and Trends of Clientelism in Turkey', pp.54, 55ff.

25. Sayanı, 'Political Patronage in Turkey', p.265.

26. Atiyas and Sayın, Siyasi Sorumluluk, Yönetsel Sorumluluk ve Bütçe Sistemi: Bir Yeniden Yapılanma Önerisine Doğru, p.29.

27. Gökhan Çapoğlu, Türkiye'de Siyasi Tıkanıklı̆̆ı Aşmak Iç̧in (Ankara: Stratejik Araştırmalar Vakfi, 1994), p.18.

28. Ibid., pp.27, 43.

29. Öniş, 'The State and Economic Development in Contemporary Turkey', p.159. The growth rates of $12.8,11.9$ and 11.2 per cent were recorded in 1951, 1952 and 1953, respectively.

30. İnan, Siyasetin İ̧̧inden, p.36.

31. Ian Budge and Hans Keman, Parties and Democracy: Coalition Formation and Government Functioning in Twenty States (New York: Oxford University Press, 1990).

32. Metin Heper and Selçuk Sancar, 'Is Legal-Rational Bureaucracy a Pre-Requisite for a Rational-Productive Bureaucracy?: The Case of Turkey', Administration and Society, Vol.30 (May 1998), pp.143-65.

33. İlter Turan, 'Stages of Political Development in the Turkish Republic', in Perspectives on Democracy in Turkey, Üstün Ergüder, Ersin Kalaycioğlu, Ergun Özbudun and İlter Turan, contributors (Ankara: Turkish Political Association, 1988), p.91 and İzak Atiyas, 'The Effect of the State's Presence in the Economy on Politics: Notes on the Reform of the State', a Paper presented at the 'Fifth National Conference on Quality in General and Political Quality in Particular', 13-14 November 1996, Istanbul.

34. Atiyas, 'The Effect of the State's Presence in the Economy on Politics: Notes on the Reform of the State', p. 338 .

35. Atiyas and Sayın, Siyasi Sorumluluk, Yönetsel Sorumluluk ve Bütçe Sistemi: Bir Yeniden 
Yapılanma Önerisine Doğru, p.28.

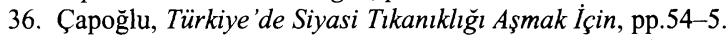

37. Erdoğan Yıldırım, Türkiye'de Siyaset Süreci ve Profesyonel Siyasette Benliğin Kurulmast: SHP Örneği (Ankara: Ark Yayınevi, 1995), pp.130-6.

38. Gökhan Çapoğlu, Yepyeni Bir Türkiye İ̧̧in (Ankara: Anadolu Stratejik Araştırmalar Vakfı, 1997), p.38.

39. İnan, Siyasetin İçinden, pp.42-4.

40. Heper, The State Tradition in Turkey, Chapter Five.

41. Güneş-Ayata, 'Roots and Trends of Clientelism in Turkey', p.59; Metin Heper, 'Negative Bureaucratic Politics in a Modernizing Context: The Turkish Case', Journal of South Asian and Middle Eastern Studies, Vol.1 (1977), pp.65-84.

42. Heper, The State Tradition in Turkey, Chapter Five.

43. Sunar, 'The Politics of State Intervention in "Populist" Egypt and Turkey', p.101.

44. Feride Acar, 'The True Path Party, 1983-1989', in Metin Heper and Jacob Landau (eds.), Political Parties and Democracy in Turkey, pp.190-5.

45. In the post-1965 period, except the early 1970s when its then leader Bülent Ecevit had its charisma at its peak, the CHP, too, gradually adopted patronage politics, as a consequence of its repeated failures at the polls. See Sayar, 'Political Patronage in Turkey', p.111.

46. For the DP period, see John Waterbury, 'Export-Led Growth and the Center-Right Coalition in Turkey', Comparative Politics, Vol.24 (January 1992), p.129.

47. Avner Levy, 'The Justice Party, 1961-1980', in Heper and Landau, Political Parties and Democracy in Turkey, pp.141, 142.

48. Güneş-Ayata, 'Roots and Trends of Clientelism in Turkey', p.54.

49. Öniş, 'The State and Economic Development in Contemporary Turkey', p.159.

50. Sunar, 'The Politics of State Intervention in 'Populist' Egypt and Turkey', p.104.

51. Joel S. Migdal, Strong States and Weak States: State-Society Relations and State Capabilities in the Third World (Princeton: Princeton University Press, 1988), p.22.

52. Ziya Önis, 'International Context, Income Distribution and State Power in Late Industrialization: Turkey and South Korea in Comparative Perspective', New Perspectives on Turkey (Istanbul), Vol.13 (Fall 1995), p.26.

53. Üstün Ergüder, 'The Motherland Party, 1983-1989', in Heper and Landau, Political Parties and Democracy in Turkey, p.156.

54. Atiyas, 'Uneven Governance and Fiscal Failure: The Adjustment Experience in Turkey', p.292.

55. Sabri Sayarı, 'Political Parties, Party Systems, and Economic Reforms: The Turkish Case', Studies in Comparative International Development, Vol.31 (Winter 1996/97), p.35

56. Cevat Karataş, 'Public Debt, Taxation System and Government Spending Changes in Turkey, 1980-1992', Journal of Economics and Administrative Studies (Istanbul), Vol.6 (1992), p.47.

57. Atiyas, 'Uneven Governance and Fiscal Failure: The Adjustment Experience in Turkey', p.293.

58. Ziya Öniş, 'Globalization and Financial Blow-Ups in the Semi-Periphery: Perspectives on Turkey's Financial Crisis of 1994', New Perspectives on Turkey, Vol.15 (Fall 1996), p.7.

59. Ergüder, 'The Motherland Party, 1983-1989', in Heper and Landau, Political Parties and Democracy in Turkey, pp.155ff.

60. Işın Çelebi, Aykut Toros and Necati Aras, Siyasette Kilitlenme ve Çözüm (Istanbul: Milliyet Yayınları, 1996), p.15.

61. If one of the authors may be allowed a personal note: in those years, Heper once asked a shopkeeper if he liked Özal. The shopkeeper told Heper that he did not like Özal because Özal often took too stern measures in the economy. Then, the shopkeeper paused for a moment and then added: 'But Özal may make a speech on the TV tonight and I would in all probability change my mind.'

62. İnan, Siyasetin İçinden, p.102.

63. Sabri Sayarı, 'Politics and Economic Policy Making in Turkey', in Tevfik F. Nas and Mehmet Odekan (eds.), Economics and Politics of Turkish Liberalization (Bethlehem, PA: Lehigh University Press, 1992).

64. Öniş, 'The State and Economic Development in Contemporary Turkey', p.160, 166 and 
idem, 'International Context, Income Distribution and State Power in Late Industrialization: Turkey and South Korea in Comparative Perspective', p.29.

65. Waterbury, 'Export-Led Growth and the Center-Right Coalition in Turkey', p.134.

66. Sayarı, 'Political Parties, Party Systems, and Economic Reforms: The Turkish Case', p.39.

67. Sunar, 'Populism and Patronage: The Demokrat Party and its Legacy in Turkey', p.756.

68. Betül Uncular, Işste Böyle Bir Meclis, 1983-1991 (Ankara: Bilgi Yayınevi, 1991), p.154.

69. Çelebi et al, Siyasette Kilitlenme ve Çözüm, pp.15-16.

70. Ergüder, 'The Motherland Party, 1983-1989', in Heper and Landau, Political Parties and Democracy in Turkey, p.165.

71. Atiyas, 'Uneven Governance and Fiscal Failure: The Adjustment Experience in Turkey', p.296.

72. Karataş, 'Public Debt, Taxation System and Government Spending Changes in Turkey, 1980-1992', p.70.

73. Atiyas, 'Uneven Governance and Fiscal Failure: The Adjustment Experience in Turkey', pp.298-9.

74. Çelebi et al., Siyasette Kilitlenme ve Çözüm, p.16.

75. Ziya Öniş, 'The Political Economy of Export-Oriented Industrialization in Turkey', in Çiğdem Balım, Ersin Kalaycıoğlu, Cevat Karataş, Gareth Winrow and Feroz Yasamee (eds.), Turkey: Political, Social and Economic Challenges in the 1990s (Leiden: E. J. Brill, 1995), p.123.

76. Güneş-Ayata, 'Roots and Trends of Clientelism in Turkey', p.58. Later it was reported that during his first 500 days in office Demirel shook hands with 113,117 persons! Milliyet (Istanbul daily), 15 April 1993.

77. Cumhuriyet (Istanbul daily), 12 December 1992. Çiller could not get along with the key higher civil servants, too. She could not put up with those civil servants who disagreed with her openly. There were also claims that at times she asked civil servants to 'doctor' some figures in order to show the performance of the government in a more positive light. She removed a number of civil servants from their posts; some others resigned.

78. Hürriyet (Istanbul daily), 4 March 1992.

79. Milliyet (Istanbul daily), 23 December 1992.

80. Bayram Gazetesi (newspaper published on religious holidays), 12 June 1992. Here Demirel referred to the pre-1987 period when the trade unions faced some legal constraints.

81. Cumhuriyet, 19 January 1992.

82. Öniş, 'Globalization and Financial Blow-Ups in the Semi-Periphery: Perspectives on Turkey's Financial Crisis of 1994', p.10.

83. Ibid., pp.10-11.

84. See, for instance, Milliyet, 8 July 1992.

85. Atiyas and Sayın, Siyasi Sorumluluk, Yönetsel Sorumluluk ve Bütçe Sistemi: Bir Yeniden Yapllanma Önerisine Doğru, p.29.

86. Çapoğlu, Yepyeni Bir Türkiye İçin, pp.26-7.

87. Earlier Erbakan's Refah Party had proposed a parliamentary investigation concerning the allegations about Çiller; they voted against their own proposal once they came to power. Before Çiller had agreed to enter a coalition with Erbakan, the other party leaders had turned down Erbakan.

88. According to this policy, profit was permitted but not interest, monopolies were to be eliminated completely, and the income tax was to be replaced by a production tax. See David Shankland, 'The Demise of Republican Turkey's Social Contract', Government and Opposition, Vol.31 (Summer 1996), p.315.

89. It was reported that the costs to the economy of the first round of promises made by Erbakan was half a quadrillion Turkish lira. Hürriyet, 2 July 1996.

90. Milliyet, 23 March 1997.

91. Hürriyet, 21 September 1996; Milliyet, 19 July 1996; Sabah, 13 May 1997.

92. Yeni Yüzyll (Istanbul daily), 7 August 1996; Hürriyet, 16 April 1997; Sabah (Istanbul daily), 13 May 1997.

93. At the time, Çiller was Deputy Prime Minister and Foreign Minister. She spent most of her time trying to hold her party together because many members of her party had begun to be 
disgruntled about the developments in question. She also tried to make Turkey a full member of the European Union but she was not successful in bringing about any progress in that direction. One reason was that she had lost the confidence of Western leaders; in the past she had promised many things to them but had not delivered. Particularly critical here was her statement in the past that for Turkey the Refah Party was a greater threat than the separatist Kurdish organization PKK and then her decision to enter a coalition government with that party. At some point Çiller even could say that 'politics was at the disposal of religion' (Hürriyet, 21 February 1997).

94. See, for instance, Metin Heper, 'Islam and Democracy in Turkey: Toward a Reconciliation?' Middle East Journal, Vol.51 (Winter 1997), pp.32-45.

95. The view that, in the Third Turkish Republic (from 1980 to the present), the military became increasingly reluctant to take power once more into its own hands is supported by a recent study of the memoirs and statements of the last three chiefs of general staff. See Metin Heper and Aylin Güney, 'The Military in the Third Turkish Republic', Armed Forces and Society, Vol.22 (Summer 1996), pp.619-42.

96. Turkey's 1982 Constitution stipulates that governments are obliged to give priority to the recommendations made by the National Security Council.

97. At the December 1995 national elections, 21 per cent of the voters cast their votes for the Refah Party. According to a survey carried out in 1994, only one-third of the voters of the party voted for that party because the party was a religiously oriented party and there is little doubt that only a small percentage of this group of voters longs for an Islamic state. For an elaboration, see Heper, 'Islam and Democracy in Turkey: Toward a Reconciliation?' pp.35-38.

98. Earlier, Erbakan and Çiller had agreed that this office of prime minister should rotate and that in summer 1998 Çiller should succeed Erbakan.

99. Migdal, Strong Societies and Weak States: State-Society Relations and State Capabilities in the Third World, pp.259ff. 